\title{
Insider vs. Outsider: Choosing Local Market Knowledge Source in the Emerging Market
}

\author{
Mike Chen-ho Chao ${ }^{1} \&$ Shan Feng ${ }^{1}$ \\ ${ }^{1}$ Cotsakos College of Business, William Paterson University, Wayne, U.S.A \\ Correspondence: Mike Chen-ho Chao, Cotsakos College of Business, William Paterson University, 1600 Valley \\ Road, Wayne, New Jersey 07470, U.S.A. Tel: 1-973-720-3746. E-mail: chaoc@wpunj.edu
}

Received: September 13, 2014

Accepted: October 14, 2014

Online Published: October 25, 2014

doi:10.5539/ibr.v7n11p85

URL: http://dx.doi.org/10.5539/ibr.v7n11p85

\begin{abstract}
Since multinational corporations (MNCs) in host countries frequently face location-based disadvantages, local market knowledge acquisition has become an increasingly important topic in the knowledge management literature. Within this research stream, the process of local market knowledge transfer has been widely discussed. However, the issues of the source (especially the internal and external sources) for MNCs to obtain local market knowledge have not been well studied, especially in the emerging market context. Also, the consequence of choosing a local market knowledge source, which interests practitioners more, rarely appears in the literature.

This study aims to be the first conceptual paper discussing both antecedents and outcomes of choosing either inside or outside local market knowledge source in the emerging market context. The framework we propose, using MNCs as the unit of analysis, includes both micro-environmental factors (organizational culture and the home market performance of MNCs) and macro-environmental factor (the openness of the economic system in the emerging market) that impact the local market knowledge source choice (insider or outsider) of MNCs. In addition, we discuss how the extent of the environmental turbulence (especially market turbulence) in the emerging market moderates the relationship between either inside or outside local market knowledge source and the performance of MNCs in the emerging market.

We believe our framework is a parsimonious and systematically clear way of explaining what is actually a complicated phenomenon and we hope that this paper provides a conceptual framework, which stimulates subsequent empirical studies.
\end{abstract}

Keywords: local market knowledge source, market turbulence, organizational culture

\section{Introduction}

Since multinational corporations (MNCs) in host countries frequently face location-based disadvantages, local market knowledge acquisition has become an increasingly important topic in the knowledge management literature. Within this research stream, the process of local market knowledge transfer has been widely discussed. For examples, Makino and Delios (1996) argued that the need for cooperating with a local partner to acquire local market knowledge decreases as MNCs' experience in a host country increases. Lord and Ranft (2000) claimed that both nature of local market knowledge itself and differences in organizational structures significantly influence the extent of MNCs' internal transfer of local market knowledge.

Different from the process of local market knowledge transfer, the issues of the source (especially the internal and external sources) for MNCs to obtain local market knowledge have not been well studied. Though scholars did have spent a lot of efforts on evaluating both inside and outside knowledge sources (e.g. Athos \& Pascale, 1981; Brewer, 1979; Katz \& Allen, 1982; Menon \& Pfeffer, 2003), there is still no consensus about which knowledge source is more preferred and few of these studies specifically focus on "local market knowledge source", let alone discuss this issue in the emerging market context. Also, the consequence of choosing a local market knowledge source, which interests practitioners more, are rarely discussed (e.g. Chung, Rogers, Lubatkin, \& Owers' 1987 research investigated how the financial performance of a firm influences its decision of hiring a new CEO from internal or external source without discussing the subsequent outcome of that choice).

This paper aims to be the first conceptual paper discussing both antecedents and outcomes of choosing either inside or outside local market knowledge source in the emerging market context. In order to accomplish this goal, 
the framework we present, using multinational corporations (MNCs) as the unit of analysis, includes both micro-environmental factors (organizational culture and the home market performance of MNCs) and macro-environmental factor (the openness of the economic system in the emerging market) that impact the local market knowledge source choice (insider or outsider) of MNCs. Furthermore, we discuss how the extent of the environmental turbulence in the emerging market moderates the relationship between either inside or outside local market knowledge source and the emerging market performance of MNCs.

The rest of the paper is organized as follows. First, we review relevant literature on knowledge management and insider vs. outsider, and briefly define organizational culture and the emerging market. Second, theories are used to build a conceptual framework from which propositions are developed. Finally, we present our conclusions and some implications are discussed.

\section{Literature Review}

The research questions of this study is how the organizational culture and home market performance influence MNCs' choice of local market knowledge source (insider or outsider) when they enter emerging markets and what will be the consequence of that choice. Obviously, knowledge, source, organizational culture, and emerging markets are four major components of above research questions. In order to facilitate our discussion, we think it is necessary to review knowledge management and insider vs. outsider literature and define organizational culture and the emerging market first which can reprove the existence of research gaps we mentioned in the introduction and serve as the base to develop propositions in the later part of this paper.

\subsection{Knowledge Management}

Knowledge management has been an increasingly important topic among researchers over the last few years. Some scholars even predict that the winners in tomorrow's market will be the masters of knowledge management (Arthur, 1996; Nonaka \& Takeuchi, 1995). In this filed of literature, knowledge transfer process is no doubt a main subtopic. With regard to the process of knowledge transfer, literature can be divided into two dimensions: intra- and inter-organizational knowledge transfer.

Within a company, knowledge transfer provides great opportunities for units to learn mutually and cooperate with each other and it helps a firm to stimulate the creation of new knowledge and contribute to each unit's ability to innovate (e.g. Kogut \& Zander, 1992; Tsai \& Ghoshal, 1998). Thomas-Hunt, Ogden, \& Neale's research (2003) found that socially isolated members participate in discussions and express their unique knowledge more than socially connected members do. Socially connected members emphasize more on the unique knowledge contributions of the socially isolated members than on those of their socially connected other, but more favorably evaluate their socially connected other's contributions than socially isolated members'. In addition, perceived experts are more likely to share their knowledge with other members and respect other member's unique knowledge contributions than non-experts. Tsai's empirical study (2001) revealed that companies' units which have higher absorptive capacity can produce more innovations and enjoy better performance if they are in the central network positions because of their easy access to new knowledge developed by other units. The nature of knowledge being transferred also plays a critical role in the knowledge transfer process. Szulanski (1996) argued that the major barriers to internal knowledge transfer are mostly knowledge-related factors such as the recipient's lack of absorptive capacity, causal ambiguity, and an arduous relationship between the source and the recipient.

Since the knowledge transfer process within an organization is far from trivial in the literature, it is clear that knowledge transfer occurring in an inter-organizational setting should be more complicated. Wang, Tong, and Koh (2003) developed a two-stage model describing the knowledge transfer process from MNCs to their subsidiaries and argued that parent company's expatriate competencies and willingness to transfer knowledge and subsidiary's capacity and intent to acquire knowledge influence the result of the knowledge transfer. Except in acquisitions there have been a lot of efforts spent on studying knowledge transfer within a single company, in alliances and JVs, and between independent firms (Bresman, Birkinshaw, \& Nobel, 1999). One of the few studies on knowledge transfer in acquisitions is conducted by Bresman, Birkinshaw, and Nobel (1999). Their results showed that imposed one-way knowledge transfer from the acquirer to the acquired characterizes the immediate post-acquisition period. Though the quantity is low, service industries are also investigated in the literature. Grosse (1996) examined the knowledge transfer process from parent companies to foreign affiliates in five service industries and found that two major forms of knowledge transfer in service industries are training and expert transfer, and higher ownership percentage of parent firms in affiliates leads to greater knowledge transfer from parent firms to affiliates. There are some country-comparison studies. One of the examples is Kotabe, Martin, and Domoto's empirical research (2002) which found that relationship duration between buyer 
and supplier in both Japanese and American automotive industries does not affect small-scale technical exchange, but higher-level technology transfer.

In agreement with what we mentioned in the introduction, knowledge transfer process, which includes local market knowledge transfer, has really been well studied by scholars. However, it is obvious that the issues of local market knowledge source, which is one of the important strategic decisions for MNCs' entering emerging markets, have not been the main focus for a long time.

\subsection{Insider vs. Outsider}

Though scholars have conducted many studies on inside and outside knowledge sources, there is still no consensus about which knowledge source is more preferred and few of these studies specifically focus on "local market knowledge source." Obviously, scholars in this research stream can be labeled as either advocator for insider or advocator for outsider.

\subsubsection{Advocator for Internal Knowledge Source}

Katz and Allen (1982) argued that the "not-invented-here" (NIH) syndrome represents one of the most important reasons why companies should go for internal knowledge source, because there is a bias against ideas from the outside. Usually, managers in the same organization stick together in closely knit in-groups and they perceive internal knowledge as superior to external knowledge. Apple Computer in the early 1990s serves as a good example about this phenomenon. Managers rejected good external ideas and lived in what was widely known as their own "reality distortion field" (Burrows, 2000, p. 102). One of the few studies that compared inside and outside knowledge transfer in multiunit companies found that organizational units benefit more from the internal knowledge than from the external knowledge (Darr, Argote, \& Epple, 1995). However, we need to know that transferring knowledge is not the same as valuing it. In other words, though availability increases the ease of communication between insiders which makes internal knowledge may be transferred more often than external knowledge (Darr, Argote, \& Epple, 1995), it does not mean that internal knowledge is better than external knowledge.

\subsubsection{Advocator for External Knowledge Source}

Although the theories of in-group favoritism and out-group derogation seem like supporting the NIH syndrome well (e.g. Brewer, 1979), what happened in practice frequently contradicts it. For example, US corporations and writers adored Japanese management practices a lot in the 1980s (e.g. Athos \& Pascale, 1981). Managers often perceive the analysis of outside consultants more valuable than suggestions provided by inside employees, even when they both bring to an end saying the same thing (Menon \& Pfeffer, 2003). Studies of inter-organizational diffusion also revealed that firms frequently transfer knowledge, strategy structures, and management practices from outsiders (e.g. Burt, 1992; Davis, 1991; Haunschild, 1993; Haveman, 1993; Mizruchi, 1992) even to the point of pursuing managerial fads and fashions (Abrahamson, 1996).

Broad preference for external knowledge in practice brings scholars to study why it looks like outside knowledge source is more preferred than inside knowledge source. They found some possible explanations for this phenomenon. For example, organizational boundaries separate an arena within which competition for promotions, status, and salaries occurs. There is a small incentive for people to adopt an insider's knowledge, because they often cannot get a lot of personal self-enhancement instead face the prospect of legitimating a direct competitor for organizational rewards. Adversely, managers are motivated to learn from competitors because they fear being outcompeted in the marketplace, and they can learn and borrow without facing the status costs of validating a direct competitor (Menon \& Pfeffer, 2003).

Another explanation is though the relative availability of internal knowledge makes it easy to be transferred (Cyert \& March, 1963), availability can simultaneously reduce its valuation. On the other hand, the relative difficulty of transferring external knowledge makes it scarce and unique, which increases its perceived value (Cialdini, 2001). Moreover, the flaws of internal knowledge are more visible because they can be examined more closely. In contrast, managers cannot scrutinize the ideas of outsiders as closely as they can for the inside knowledge, so the flaws of external ideas are less visible until such ideas are brought inside and actually implemented (Menon \& Pfeffer, 2003).

\subsubsection{Organizational Culture}

The definition of organizational culture is diverse. According to Hellriegel, Slocum, and Woodman (1995, p. 466), "organizational culture represents a complex pattern of beliefs, expectations, ideas, values, attitudes, and behaviors shared by the members of an organization." However, Hofstede (1997) argued that though in the management literature organizational culture has often been presented as a matter of values (e.g. Peters \& 
Waterman, 1982), this type of definition causes confusion because the values of founders and those of the employees are not distinguished in the literature. "Founders and leaders create the symbols, the heroes and the rituals that constitute the daily practices of the organization's members. However, members have to adapt their personal values to the organization's needs, to a limited extent only...The values of employees cannot be changed by the employers, because they were acquired when the employers were children" (P. 490). Though different definitions of organizational culture are provided by Hofstede and other management researchers, there is still some consensus among them, which is organizational culture, rather than national culture, is manageable.

In this paper, we adopt Hofstede's definition (1997). It means five dimensions of organizational culture: process versus result-oriented, job versus employee-oriented, professional versus parochial, tightly versus loosely-controlled, and pragmatic versus normative will be included in our discussion. We will further define these dimensions later in the proposition part.

\subsection{Emerging Market}

According to Hoskisson, Eden, Lau, and Wright (2000), emerging markets are markets that are growing fast economically but structurally volatile in the course of economic liberalization and transformation. Some example markets are Russia, China, Brazil, South Africa, etc. MNCs may be interested in the promise of fast growing emerging markets, but they need to be cautious when evaluating potential investments there. In fact, emerging-market investments are exposed to additional risks, including accelerated inflation, exchange rate fluctuations, adverse repatriation laws and fiscal measures, and macroeconomic and political distress. These risks definitely call for a different approach to invest in the emerging market (Goedhart \& Haden, 2003).

\section{Conceptual Framework and Propositions}

\subsection{Organizational Culture and MNCs' Local Market Knowledge Source Choice}

There are actually six dimensions of organizational culture in Hofstede's definition (1997). However, we exclude one dimension, open system versus closed system cultures, because it is tautological to discuss it in the proposition (By definition, open system culture is a culture which prefers external communication; closed system culture is a culture which prefers internal communication).

Process-oriented culture is dominated by technical and bureaucratic routines and result-oriented culture is dominated by a common concern for outcomes (Hofstede, 1997). This dimension can be seemed as concerning the culture's degree of homogeneity. In process-oriented culture, members of MNCs perceive their work in about the same way. However, in resulted-oriented culture, everyone looks at his or her practice differently. Compared to inside local market knowledge, outside local market knowledge is usually more different than MNCs' existing knowledge and is easier being accepted by result-oriented culture. Thus,

Pla: MNCs with result-oriented organizational culture will acquire more outside local market knowledge than MNCs with process-oriented culture do.

Job-oriented culture assumes that the only responsibility for employees is their job performance. On the other hand, employee-oriented culture assumes a broad responsibility for companies, which is their employees' well-being (Hofstede, 1997). In order to take care of its employees first, internal local market knowledge will have priority to be accepted in employee-oriented culture since employees whose suggestions being adopted will be rewarded. Thus,

PIb: MNCs with job-oriented organizational culture will acquire more outside local market knowledge than MNCs with employee-oriented culture do.

In the company with professional culture, members primarily identify themselves with their profession. On the other hand, members in the parochial-culture company derive their identity from the organization where they work (Hofstede, 1997). Since external local market knowledge is definitely from units outside the walls of MNCs, MNCs with parochial culture is less likely to accept local market knowledge provided by outsiders. Thus,

P1c: MNCs with professional organizational culture will acquire more outside local market knowledge than MNCs with parochial culture do.

The dimension of tightly versus loosely controlled culture deals with the degree of formality and punctuality within the company. Tightly controlled culture is more formal and regular than loosely controlled one (Hofstede, 1997). Since internal local market knowledge usually follows a MNC's old thinking process, it is more likely for a MNC with tightly controlled culture to accept it. Thus,

Pld: MNCs with loosely controlled organizational culture will acquire more outside local market knowledge 
than MNCs with tightly controlled culture do.

Pragmatic culture is more flexible of dealing with the environment, in particular with customers than normative culture is. Thus, external local market knowledge is more likely to be accepted by a MNC with a pragmatic culture.

Ple: MNCs with pragmatic organizational culture will acquire more outside local market knowledge than MNCs with normative culture do.

\subsection{Home Market Performance of MNCs and MNCs' Local Market Knowledge Source Choice}

There is an agreement among scholars that bad-performance companies often need to hire outside CEOs because they are more likely to be able to change existing strategies and values that caused the current problems than insiders. The reason is that outsiders are able to take decisive action to turn around a bad situation, while insiders are probably to be slow in recognizing the urgency of current problems and may pursue the old strategies that are no longer effective (Chung et al., 1987). The same logic can be applied to MNCs' choice of local market knowledge source in the emerging market. MNCs with worse home market performance are more likely to acquire outside local market knowledge since they have lost their confidence on their own knowledge source. It is worthy to note that though in Chung et al.'s study (1987) they measured corporate performance by measuring changes in profitability and stock price, in this paper either home or emerging market performance of MNCs is a general concept due to its theoretical nature. In other words, the market performance of MNCs can refer to financial, marketing, or both performances. Thus,

\section{P2: MNCs with worse home market performance will acquire more outside local market knowledge.}

\subsection{The Moderating Effect of Openness of the Economic System in the Emerging Market}

According to Tellis, Stremersch, and Yin (2003), openness of the economic system in the emerging market could be defined as the extent to which the market is involved in international trade. Since the definition of emerging markets is not clear compared to those of developed or newly industrial countries (Glen, Lee, \& Singh, 2003), the variance of the countries categorized in the emerging market is large. So, some emerging markets involve more in international trade than others (Goedhard \& Haden, 2003). Since emerging markets which involve more in international trade have greater opportunities to communicate and learn mutually from developed countries, they know the importance of establishing governmental or private mechanism which can attract and help foreign companies' businesses to and in their markets (Goedhard \& Haden, 2003). So, in these markets, it is easier for MNCs to get external local market knowledge. Adversely, in the closer economic system, even MNCs want to access outside local market knowledge, they cannot do it due to the lack of availability. Thus,

P3: More open the economic system in the emerging market is, the easier for MNCs to access outside local market knowledge.

3.4 The Moderating Effect of Environmental Turbulence in the Emerging Market on the Relationship between MNCs'Local Market Knowledge Source Choice and Their Emerging Market Performance

The choice of local market knowledge source constitutes the basic ingredients of emerging market performance of MNCs (Sheremata, 2000; Van de Ven, 1980, 1986). This link is based on the resource-based view of the firm (Barney, 1991). Per this view, the choice of local market knowledge source is intangible and higher-order capability that enables a firm to perform critical activities better than its competitors. Doing business in developed countries is totally different from doing it in the emerging market. Like what Goedhart and Haden mentioned (2003), emerging-market investments are exposed to additional risks, including accelerated inflation, exchange rate fluctuations, adverse repatriation laws and fiscal measures, and macroeconomic and political distress, and these risks definitely call for a different approach to investment. Because of these risks or differences, MNCs cannot totally control the trend in the emerging market and need to depend more on local partners, which have more accurate local market knowledge.

By acquiring external local market knowledge, the choice of outside local market knowledge may promote faster learning and competence development of MNCs in the emerging market. This learning may enhance the development of knowledge of customer requirements. Further, the choice of external local market knowledge makes it likely that MNCs will introduce products, which contain ideas about market that may be more advanced than what competing products have. Thus, MNCs able to acquire a large amount of external local market knowledge faster is more likely to get high-quality knowledge that allows MNCs to solve problems associated with the performance requirements of customers such as reliability and durability, and to do so in a timely manner. It follows that external local market knowledge in the emerging market increases MNCs' market performance (Brown \& Eisenhardt, 1995). 
P4: MNCs which acquire more local market knowledge from external source will have better emerging market performance.

In most of the cases, a MNC having the ability to introduce a new product meeting more customer expectations than its competitors has greater opportunity to win the market. However, these cases may not be true anymore under the emerging market. As we mentioned before, it is more complicated for MNCs operating in the emerging market than in the developed or newly industrial countries, because emerging markets have different attributes, and usually we call these differences "environmental turbulence." Environmental turbulence includes technology and market turbulences. Technology turbulence is defined as the rate of change associated with new product technologies, and market turbulence is defined as the rate of change associated with the composition of customers, customer preferences, and competitor strategies (Jaworski \& Kohli, 1993). In this paper, because we are looking at local market knowledge, we just take market turbulence into account. So, the contribution of external local market knowledge to MNCs' emerging market performance becomes depending on the amount of turbulence in the emerging market. The moderating impact of turbulence exists in these markets because learning processes take MNCs time to adjust to changes in the environment. In other words, in turbulent environments, identifying customer needs and translating them into technical specifications become more complex. Even companies with satisfying new product, their advantages will be offset as quickly as customer composition, customer preference, and competitor strategies change. With these turbulences, MNCs' market performance will be negatively moderated even they have better ideas of customers in the emerging market. Thus,

P5: Proposition 4 will be negatively moderated by the market turbulence in the emerging market.

\section{Implications and Conclusions}

Organizational culture is "manageable" because it is composed of practices rather than value (Hofstede, 1997). So, given that outside local market knowledge source is more useful for MNCs entering turbulent environments, senior managers should try to make their companies' organizational culture more result-oriented, job-oriented, professional-oriented, loosely-controlled, and pragmatic which are more suitable for acquiring outside local market knowledge in the emerging market. It is worthy to reemphasize the importance of conducting accurate and comprehensive host market research before MNCs decide to enter foreign markets, because the extent of environmental turbulence of these unfamiliar markets can unexpectedly damage a good product's market performance.

Consistent with its purpose, this study develops a more complicated (including both micro- and macro-environmental antecedents and specially discussing the performance variable), yet more refined understanding of MNCs' choice of local market knowledge source. Also, different from previous work, this study focuses on the emerging market context characterized by turbulent environments. All of these contributions make this paper represent a worthwhile extension of the research published to date.

We believe our framework is a parsimonious and systematically clear way of explaining what is actually a complicated phenomenon. However, it will not be surprising that some scholars critique this study of not taking all possible influences into account. For examples, individual decision makers' characteristics (e.g. educational background) and market conditions (e.g. the degree of competition in the marketplace) might impact MNCs' choice of local market knowledge source (Menon \& Pfeffer, 2003). Moreover, the correlation between the home market performance of MNCs and their host market performance could be high which impedes the accuracy of our propositions about the relationships among local market knowledge source, host market performance, and environmental turbulence. Further research needs to be done to make this framework more comprehensive and special attention should be paid to the correlation problem between MNCs' home and host market performance. In addition, though we assume the "choice" reflects a firm's "preference" for a certain knowledge source, the differentiation between these two concepts should be delineated. Sometimes a knowledge source could be preferred but finally not be chosen by a company because of availability or other reasons. This topic is not included in this paper but should be discussed by scholars in the future. 


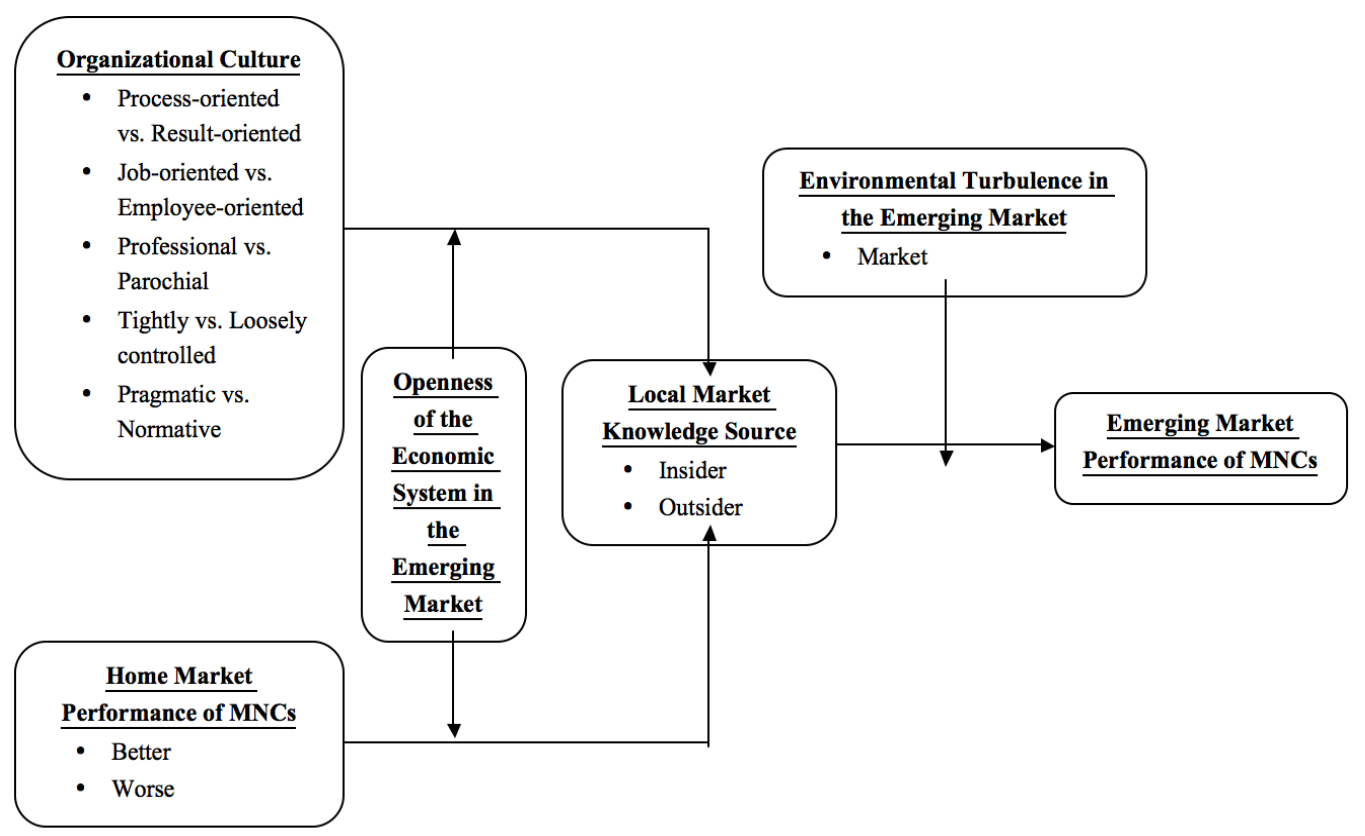

Figure 1. Framework of antecedents and outcomes of local market knowledge source choice in the emerging market

In conclusion, we believe that local market knowledge source choice has considerable potential for further research. There is a need for empirical tests of local market knowledge source choice and more detailed examination of the concepts and relationships we present in this paper. We hope that this paper provides a conceptual framework, which stimulates subsequent studies.

\section{References}

Abrahamson, E. (1996). Management fashion. Academy Management Review, 21, 254-285. http://dx.doi.org/10.2307/258636

Arthur, W. B. (1996). Increasing returns and the new world of business. Harvard Business Review, 74(4), 100110.

Athos, A. G., \& Pascale, R. T. (1981). The art of Japanese management. New York: Simon and Schuster.

Barney, J. B. (1991). Firm resources and sustainable competitive advantage. Journal of Management, 17, 99-120. http://dx.doi.org/10.1177/014920639101700108

Bresman, H., Birkinshaw, J., \& Nobel, R. (1999). Knowledge transfer in international acquisitions. Journal of International Business Studies, 30(3), 439-462. http://dx.doi.org/10.1057/palgrave.jibs.8490078

Brewer, M. B. (1979). Ingroup bias in the minimal intergroup situation: A cognitive-motivational analysis. Psychological Bulletin, 86, 307-324. http://dx.doi.org/10.1037/0033-2909.86.2.307

Brown, S., \& Eisenhardt, K. (1995). Product development: Past research, present findings, and future directions. Academy of Management Review, 20(April), 343-378. http://dx.doi.org/10.5465/AMR.1995.9507312922

Burrows, P. (2000). Apple; Yes, Steve, you fixed it. Congrats! Now what's act two? Business Week, 3692, 102112.

Burt, R. S. (1992). Structural holes. Cambridge, MA: Harvard University Press.

Chung, K. H., Rogers, R. C., Lubatkin, M., \& Owers, J. E. (1987). Do insiders make better CEOs than outsiders? The Academy of Management Executive, 1(3), 323-329.

Cialdini, R. B. (2001). Influence. Needham Heights, MA: Allyn \& Bacon.

Cyert, R. M., \& March, J. G. (1963). A behavioral theory of the firm. Englewood Cliffs, NJ: Prentice-Hall.

Darr, E. D., Argote, L., \& Epple, D. (1995). The acquisition, transfer, and depreciation of knowledge in service organizations: Productive in franchises. Management Science, 41, 1750-1762. 
http://dx.doi.org/10.1287/mnsc.41.11.1750

Davis, G. F. (1991). Agents without principles? The spread of the poison pill through the intercorporate network. Administrative Science Quarterly, 36, 583-613. http://dx.doi.org/10.2307/2393275

Glen, J., Lee, K., \& Singh, A. (2003). Corporate profitability and the dynamics of competition in emerging markets: A time series analysis. The Economic Journal, 113(November), 465-484. http://dx.doi.org/10.1046/j.0013-0133.2003.00165.x

Goedhart, M. H., \& Haden, P. (2003). Emerging markets aren't as risky as you think. McKinsey Quarterly, 4, 66-73.

Grosse, R. (1996). International technology transfer in services. Journal of International Business Studies, 27(4), 781-800. http://dx.doi.org/10.1057/palgrave.jibs.8490153

Haunschild, P. R. (1993). Interorganizational imitation: The impact of interlocks on corporate acquisition activity. Administrative Science Quarterly, 38, 564-592. http://dx.doi.org/10.2307/2393337

Haveman, H. A. (1993). Follow the leader: Mimetic isomorphism and entry into new markets. Administrative Science Quarterly, 38, 593-627. http://dx.doi.org/10.2307/2393338

Hellriegel, D., Slocum, J. W. Jr., \& Woodman, R. W. (1995). Organizational behavior. St. Paul, MN: West Publishing Company.

Hofstede, G. (1997). The business of international business is culture. In H. Vernon-Wortzel \& L. H. Wortzel (Eds.), Strategic management in a global economy. New York: John Wiley and Sons.

Hoskisson, R. E., Eden, L., Lau, C. M., \& Wright, M. (2000). Strategy in emerging economies. Academy of Management Journal, 43(3), 249-267.

Jaworski, B. J., \& Kohli, A. K. (1993). Market orientation: Antecedents and consequences. Journal of Marketing, 57(July), 53-70. http://dx.doi.org/10.2307/1251854

Katz, R., \& Allen, T. J. (1982). Investigating the not invented here (NIH) syndrome: A look at the performance, tenure, and communication patterns of $50 \mathrm{R} \& \mathrm{D}$ project groups. $R \& D$ Management, 121, 7-19. http://dx.doi.org/10.1111/j.1467-9310.1982.tb00478.x

Kogut, B., \& Zander, U. (1992). Knowledge of the firm, combinative capabilities, and the replication of technology. Organization Science, 3, 383-397. http://dx.doi.org/10.1287/orsc.3.3.383

Kotabe, M., Martin, X., \& Domoto, H. (2003). Gaining from vertical partnerships: Knowledge transfer, relationship duration and supplier performance improvement in the U.S. and Japanese automotive industries. Strategic Management Journal, 24(4), 293-316. http://dx.doi.org/10.1002/smj.297

Lord, M. D., \& Ranft, A. L. (2000). Organizational learning about new international markets: Exploring the internal transfer of local market knowledge. Journal of International Business Studies, 31(4), 573-589. http://dx.doi.org/10.1057/palgrave.jibs.8490923

Makino, S., \& Delios, A. (1996). Local knowledge transfer and performance: Implications for alliance formation in Asia. Journal of International Business Studies, 27(5), 905-927. http://dx.doi.org/10.1057/palgrave.jibs.8490156

Menon, T., \& Pfeffer, J. (2003). Valuing internal vs. external knowledge: Explaining the preference for outsiders. Management Science, 49(4), 497-513. http://dx.doi.org/10.1287/mnsc.49.4.497.14422

Mizruchi, M. S. (1992). The structure of corporate political Action: Interfirm relationships and their consequences. Cambridge, MA: Harvard University Press.

Nonaka, I., \& Takeuchi, H. (1995). The knowledge-creating company. New York: Oxford University Press.

Peters, T. J., \&Waterman, R. H. (1982). In search of excellence: Lessons from America's best-run companies. New York: Harper \& Row.

Sheremata, W. A. (2000). Centrifugal and centripetal forces in radical new product development under time pressure. Academy of Management Review, 25, 389-408. http://dx.doi.org/10.2307/259020

Szulanski, G. (1996). Exploring internal stickiness: Impediments to the transfer of best practice within the firm. Strategic Management Journal, 17, 27-43. http://dx.doi.org/10.1002/smj.4250171105

Tellis, G. J., Stremersch, S., \& Eden, Y. (2003). The international takeoff of new products: The role of economics, culture, and country innovativeness. Marketing Science, 22(2), 188-208. 
http://dx.doi.org/10.1287/mksc.22.2.188.16041

Thomas-Hunt, M. C., Ogden, T. Y., \& Neale, M. A. (2003). Who's really sharing? Effects of social and expert status on knowledge exchange within groups. Management Science, 49(4), 464-477. http://dx.doi.org/10.1287/mnsc.49.4.464.14425

Tsai, W. (2001). Knowledge transfer in intraorganizational networks: Effects of network position and absorptive capacity on business unit innovation and performance. Academy of Management Journal, 44(5), 996-1004. http://dx.doi.org/10.2307/3069443

Tsai, W., \& Ghoshal, S. (1998). Social capital and value creation: The role of intrafirm networks. Academy of Management Journal, 41, 464-476. http://dx.doi.org/10.2307/257085

Van de Ven, A. H. (1980). Problem solving, planning and innovation- Part I: Test of the problem planning model. Human Relations, 33, 711-740. http://dx.doi.org/10.1177/001872678003301003

Van de Ven, A. H. (1986). Central problems in the management of innovation. Management Science, 32, 590607. http://dx.doi.org/10.1287/mnsc.32.5.590

Wang, P., Tong, T. W., \& Koh, C. P. (2004). An integrated model of knowledge transfer from MNC parent to China subsidiary. Journal of World Business, 39(2), 168. http://dx.doi.org/10.1016/j.jwb.2003.08.0

\section{Copyrights}

Copyright for this article is retained by the author(s), with first publication rights granted to the journal.

This is an open-access article distributed under the terms and conditions of the Creative Commons Attribution license (http://creativecommons.org/licenses/by/3.0/). 